\title{
Immunohistochemical Expression of Fibroblast Growth Factor Receptor 3 and Cyclooxygenase-2 in Urinary Bladder Carcinomas with Correlation of Schistosomiasis in Egyptian Patients
}

\author{
Randa Khaled*, Samia Gabal, Ahmad Naem \\ Department of Pathology, Cairo University of Medicine, Cairo, Egypt
}

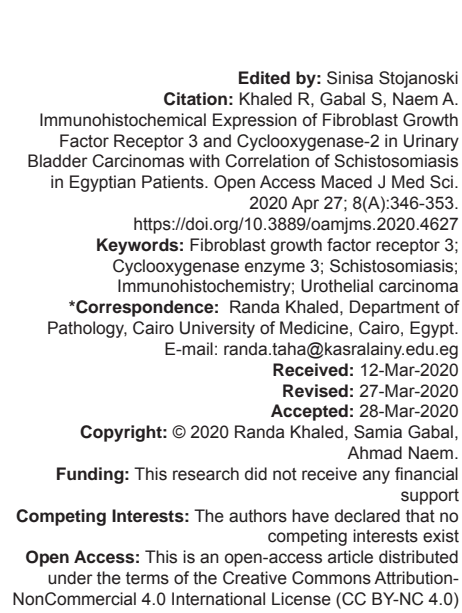

\section{Introduction}

Bladder cancer is the sixth most common cancer throughout the world [1]. It is the most common malignancy among Egyptian males. Schistosomal infection is considered a major risk factor for developing squamous cell carcinoma (SCC) [32].

At present, there are no validated prognostic molecular biomarkers such as T-cell receptor clonality and tissue or blood-based immune-gene profiling to guide the clinical management of urinary bladder cancer. Crucial therapeutic decisions are based on risk tables that include tumor size and number, previous history, in addition to histopathological criteria which are often limited by observer variability and have relatively low reproducibility [2]. Factors that include choice of antibody, fixation technique, and selection of tumor areas to measure staining methods, signal detection methods, criteria for positive staining, data interpretation guidelines, and stratification criteria are all major challenges for the clinical application of tissue-based biomarkers in urothelial bladder management [27].

Overall, urothelial cancer (UC) management would greatly benefit from cost-effective methods for screening and surveillance to predict the risks of recurrence and progression so that more targeted therapeutic regimes and intensive monitoring could be focused on patients at higher risk [2], [16], [17].

Fibroblast growth factor receptor 3 (FGFR3) has been revealed to possess an oncogenic role in numerous types of cancer, especially bladder [3]. Patients with FGFR3 alterations tend to have a low likelihood of response to chemotherapy or immune checkpoint [27]. FGFR3 mutations are found in a large proportion of low grade, low stage bladder cancers, the development of a robust test detecting these mutations would be the most obvious step. It would be a useful molecular marker in bladder cancer diagnosis and prognosis and could - in theory - provide an excellent urine marker for follow-up of patients with low grade and low stage bladder cancer [4], [5]. It could also guide the management lines in treatment-resistant 


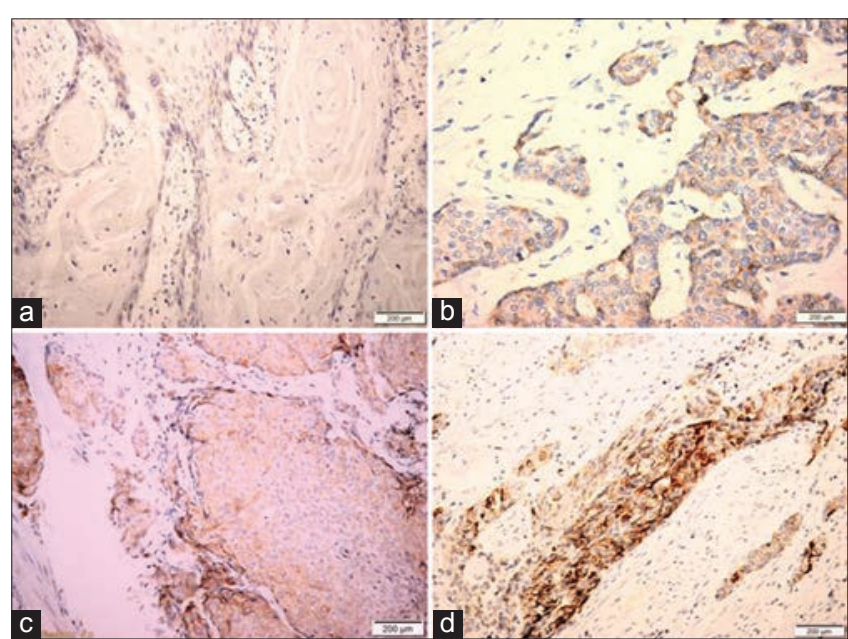

Figure 1: Variable staining degrees of expressing fibroblast growth factor receptor 3. (a) Negative staining of low-grade squamous cell carcinoma ( $\times 200$ ), (b) weak cytoplasmic and membranous staining of squamous cell carcinoma (×200), (c) moderate cytoplasmic staining of papillary transitional cell carcinoma (TCC) $(\times 200)$, (d) strong membranous and cytoplasmic staining of invasive TCC $(\times 400)$

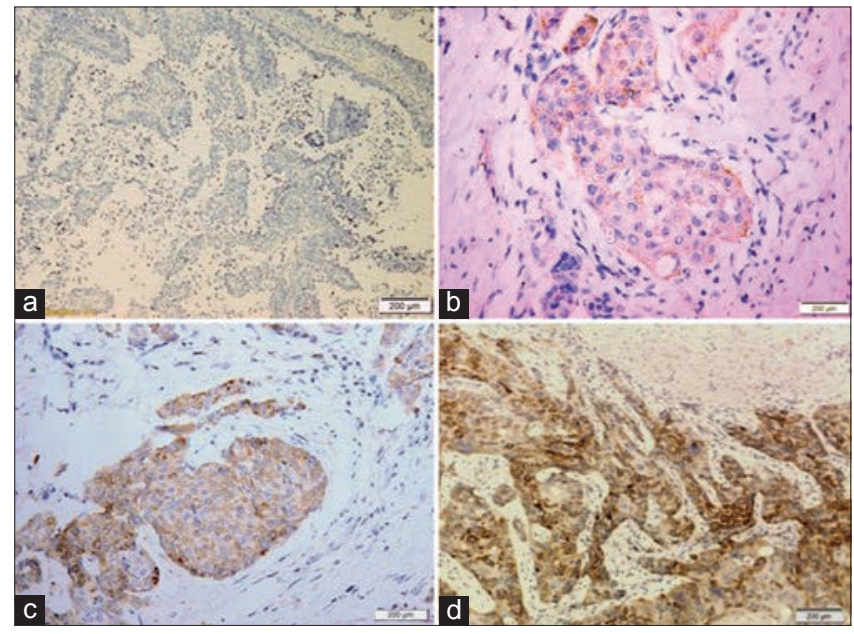

Figure 2: Variable staining degrees of expressing cyclooxygenase-2. (a) Negative staining of papillary transitional cell carcinoma (TCC) (×200), (b) weak cytoplasmic staining of low-grade squamous cell carcinoma (×200), (c) moderate membranous and cytoplasmic staining of papillary TCC (×200), (d) strong membranous and cytoplasmic staining of squamous cell carcinoma $(\times 200)$

patients to shift into FGFR inhibitors, e.g., erdafitinib and BGJ398 [28].

Cyclooxygenase-2 (COX-2) is an induced inflammatory mediator involved in the development of tumors responsible for the conversion of arachidonic acid to prostaglandins. Overexpression of COX-2 may play a role in carcinogenesis through cellular proliferation, angiogenesis, apoptosis, invasion/motility, and immune responses [18]. It is not detectable in most normal tissues; however, it is induced at sites of inflammation by cytokines, growth factors, and tumor promoters that result in upregulation of PD-L1, which increase the myeloid-derived suppressor cells in peripheral blood and eliminating CD8 T cells from urinary bladder cancer [27].

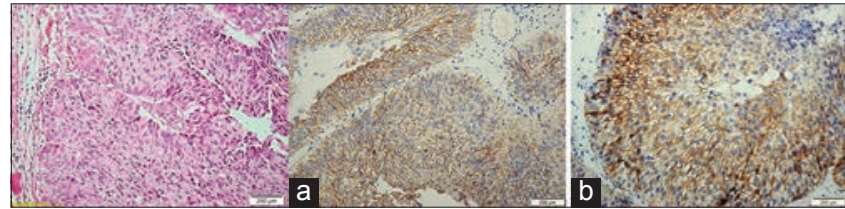

Figure 3: Non-invasive papillary transitional cell carcinoma, low-grade, $(\times 200)$ original magnification, hematoxylin and eosin stain. (a) Strong membranous fibroblast growth factor receptor 3 immunostaining, (b) strong membranous cyclooxygenase-2 immunostaining

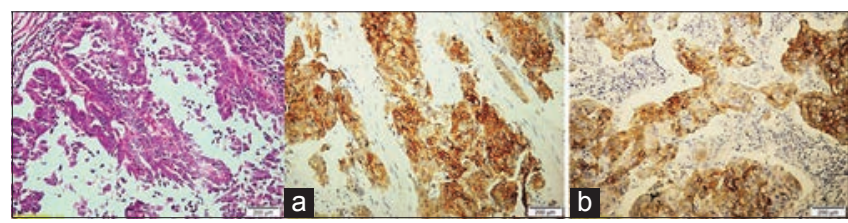

Figure 4: Invasive papillary transitional cell carcinoma, high grade, $(\times 200)$ original magnification, hematoxylin and eosin stain. (a) Strong membranous and cytoplasmic fibroblast growth factor receptor 3 immunostaining, (b) Strong membranous and cytoplasmic cyclooxygenase-2 immunostaining

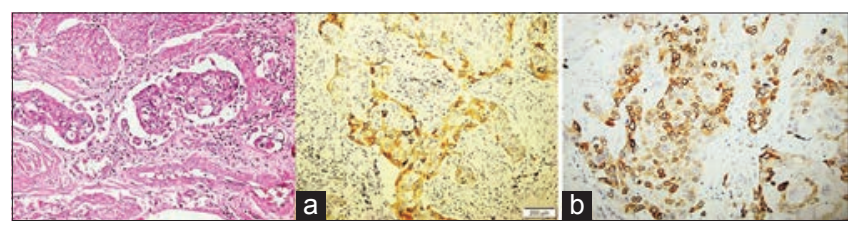

Figure 5: Squamous cell carcinoma, high grade, with evident lymphovascular emboli $(\times 200)$ original magnification, hematoxylin and eosin stain. (a) Strong membranous and cytoplasmic fibroblast growth factor receptor 3 immunostaining, (b) strong membranous and cytoplasmic cyclooxygenase-2 immunostaining

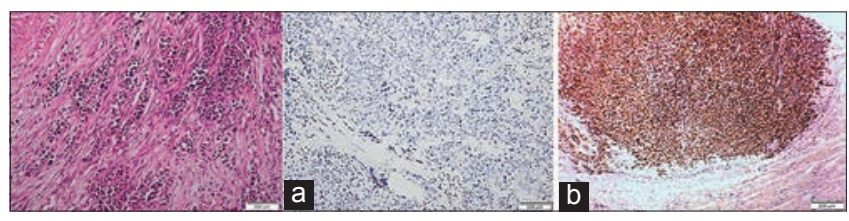

Figure 6: Small cell carcinoma, high grade, $(\times 200$ original magnification), hematoxylin and eosin stain. (a) Negative fibroblast growth factor receptor 3 immunostaining, (b) strong membranous and cytoplasmic cyclooxygenase-2 immunostaining

Schistosomiasis has been linked to induce urinary bladder cancer by increasing the proliferation of urothelium and decreasing apoptosis. The concurrent inflammation and presence of possibly mutagenic parasite molecules could explain the observation of increased chromosomal damage. In addition, there is an increase cell proliferation in endothelial cells, resulting in angiogenesis with egg granuloma formation. The resulting keratinous squamous metaplasia has been associated with the increased risk of developing squamous cell carcinoma, with approximately one-half of the cases arising subsequent to the metaplasia [29].

This study aimed at the assessment of immunohistochemical expression of FGFR3 and COX-2 in urinary bladder carcinoma in Egyptian patients, to investigate their potential role in urothelial carcinogenesis. Further assessment is targeted to 


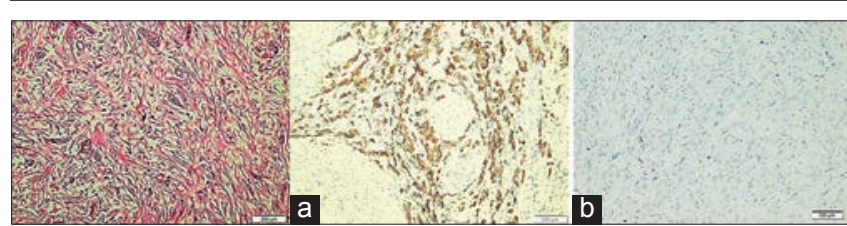

Figure 7: Sarcomatoid carcinoma with diffuse spindling, high grade, ( $\times 200$ original magnification), hematoxylin and eosin stain. (a) Strong membranous and cytoplasmic fibroblast growth factor receptor 3 immunostaining, (b) Negative cyclooxygenase-2 immunostaining

the association of their expression to the presence of bilharzia infection of these cases with the possible role of both FGFR3 and COX-2 as possible usage of therapies targeting such receptors.

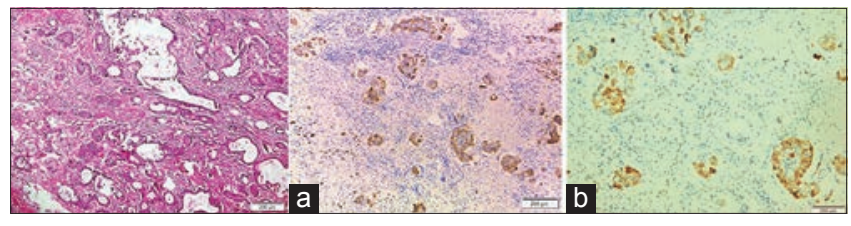

Figure 8: Transitional cell carcinoma with focal adenoid differentiation, high grade, $(\times 200)$ original magnification, hematoxylin and eosin stain. (a) Strong membranous and cytoplasmic fibroblast growth factor receptor 3 immunostaining, (b) Strong membranous and cytoplasmic cyclooxygenase-2 immunostaining

\section{Materials and Methods}

This retrospective study was carried out on 90 cases of randomly chosen formalin-fixed paraffinembedded tissue blocks of patients diagnosed with bladder carcinoma with or without coexistent schistosomal infestation from the archives of our pathology department from the period of September 2017 to July 2018. Patients were operated by radical cystectomy or transurethral resection biopsy. Clinicopathological data of all cases were recorded from the patient records and tabulated. Ethical clearance was obtained by the institutional review board prior to the study.

Each paraffin block was by cut by rotator microtome at $5 \mu$ thickness then mounted on glass slides to be stained by hematoxylin and eosin (H\&E) for histopathological re-evaluation by two pathologists and on charged glass slides for immunostaining process. The slides deparaffinized and hydrated in xylene. Then, they were treated for antigen retrieval (using a microwave oven for $30 \mathrm{~min}$ ) an automated Omnis DAKO immunostainer at a high $\mathrm{pH}$ of 8 .

Afterthis, thesectionsweretreated withantibodies using avidin-biotin-peroxidase 3\% (Thermo Scientific) for $30 \mathrm{~min}$. Diaminobenzidine tetrahydrochloride was used as a substrate and chromogen. Hematoxylin (Biogenex) was used as a counterstain. The primary antibody was a mouse monoclonal antibody of anti-FGFR3 which was manufactured by Santa Cruz Biotechnology, Inc. (Dallas, TX, clone B-9, SC-13121) and used at a dilution of 1:50.
Tumor tissue sections were examined and scored under Leica DM500 microscope at low power than high power magnification by two independent pathologists who were not informed of the histological diagnosis.

Assessment of FGFR3 expression in the tumor cells was designated as brownish cytoplasmic and/or membranous staining in more than $10 \%$ of tumor cells (threshold point of positivity). A minimum of 500 cells was counted. A case of normal skin was also sectioned and underwent the same procedure for each run performed to serve as a positive control case. FGFR3 positivity in the background stroma and in the muscle fibers served as a positive internal control.

The same steps were performed for COX-2 staining but antigen retrieval was done at a lower $\mathrm{pH}(\mathrm{pH} \mathrm{6)}$ and a case of the normal colon was also sectioned and underwent the same procedure for each run to serve as a positive control. The primary antibody was a mouse monoclonal antibody against COX2 which was manufactured by Santa Cruz Biotechnology, Inc. (Dallas, TX, clone $\mathrm{H}-3$, (sc-376861) and used at a dilution of 1:100. Assessment of COX-2 expression in the tumor cells was designated as brownish cytoplasmic and/or membranous staining in more than $10 \%$ of tumor cells (threshold point of positivity). A minimum of 500 cells was counted. COX-2 positivity in the background stroma, endothelial cells, and muscle fibers served as a positive internal control.

The data were tabulated and Chi-square test was used to examine the relation between qualitative variables. $p<0.05$ was considered significant.

All slides were screened on Leica DM500 microscope and all photos were imaged by $\mathrm{HD}$ digital microscope camera, named Leica ICC50 HD, connected to the same microscope.

\section{Results}

This study included 90 cases of urinary bladder cancer, in which the ages of the patients ranged from 41 to 79 years with a mean age of 64 years. As regards to the gender, 73 of the 90 cases were found to be males (representing $81.1 \%$ of the study) and the remaining were females (17 cases; 18.9\%). FGFR3 expression was established in 66 cases $(73.3 \%$ of the total cases). As for COX2, it was expressed in 75 cases $(83.3 \%$ of total cases). Only one-third of cases (35.5\%) showed schistosomal affection.

The majority of the cases were found to be of high grade (54 cases; $60 \%$ ) and 36 cases were of low grade (representing $40 \%$ of the study). A large percentage of the low-grade tumors showed positive expression for FGFR3 ( $p=0.028 ; 69.4 \%$ of the group). A similar pattern was also noted among the low-grade 
tumors showing a positive COX2 expression $(p=0.020$ $83.3 \%$ of the group). Further findings also showed a positive statistical correlation of positive nodal metastasis ( $p=0.0006$ ) and positive lymphovascular invasion $(L V I)(p=0.0028)$ in relation to FGFR3; however, these results were only seen in regards to LVI to COX2 expression.

As regards to tumor size in this study, FGFR3 demonstrated a positive correlation $(p=0.028)$ unlike COX2 which did not. The bladder carcinoma cases with adjacent carcinoma in situ (CIS) were seen in $34.4 \%$ of this study group and showed a strong relation with
COX2 ( $p=0.034)$ but showed an insignificant finding in correlation to FGFR3 ( $p=0.068)$.

The relationship between FGFR3 and COX2 expression and the clinicopathological variables are shown in Tables 1 and 2, respectively. The main histological subtypes included 31 cases of the conventional urothelial cell carcinoma constituting $(34.4 \%), 22$ cases of squamous cell carcinoma (25.6\%), and urothelial cell carcinoma with squamous cell differentiation (13.3\%). The remaining cases included micropapillary (4 cases), small cell (4 cases), sarcomatoid (4 cases), and urothelial cell carcinoma

Table 1: Clinicopathological characteristics of the studied cases of bladder carcinoma and its correlation with FGFR3 expression

\begin{tabular}{|c|c|c|c|c|c|c|c|}
\hline \multirow[t]{2}{*}{ Parameters } & \multicolumn{2}{|l|}{$\mathrm{n}(\%)$} & \multicolumn{2}{|c|}{ Positive FGFR3 expression } & \multicolumn{2}{|c|}{ Negative FGFR3 expression } & \multirow[t]{2}{*}{$p$ value } \\
\hline & $(n=90,100 \%)$ & $\%$ & $(n=66,73.3 \%)$ & $\%$ & $(n=24,26.7 \%)$ & $\%$ & \\
\hline \multicolumn{8}{|l|}{ Age } \\
\hline$\leq 60$ years & 43 & 47.77 & 30 & 45.45 & 13 & 54.2 & \multirow[t]{2}{*}{0.195} \\
\hline$>60$ years & 47 & 52.22 & 36 & 54.54 & 11 & 45.8 & \\
\hline \multicolumn{8}{|l|}{ Gender } \\
\hline Male & 73 & 81.11 & 56 & 84.88 & 17 & 70.83 & \multirow[t]{2}{*}{0.191} \\
\hline Female & 17 & 18.88 & 10 & 15.12 & 7 & 29.17 & \\
\hline \multicolumn{8}{|l|}{ Tumor size } \\
\hline$<3 \mathrm{~cm}$ & 30 & 33.33 & 23 & 34.88 & 7 & 29.17 & \multirow[t]{2}{*}{0.028} \\
\hline $3-5 \mathrm{~cm}$ & 31 & 34.44 & 25 & 37.89 & 6 & 25 & \\
\hline \multicolumn{8}{|l|}{ Grade } \\
\hline Low grade & 36 & 40 & 25 & 37.89 & 11 & 45.83 & \multirow[t]{2}{*}{0.028} \\
\hline High grade & 54 & 60 & 41 & 62.11 & 13 & 54.17 & \\
\hline \multicolumn{8}{|c|}{ Presence of nodal metastasis } \\
\hline Positive & 25 & 27.77 & 20 & 30.33 & 5 & 20.83 & \multirow[t]{2}{*}{0.0006} \\
\hline Negative & 65 & 72.22 & 46 & 69.67 & 19 & 79.17 & \\
\hline \multicolumn{8}{|c|}{ Muscle invasion } \\
\hline Present & 79 & 87.78 & 57 & 86.34 & 22 & 91.67 & \multirow[t]{2}{*}{0.064} \\
\hline Absent & 11 & 12.22 & 9 & 13.66 & 2 & 8.33 & \\
\hline \multicolumn{8}{|c|}{ Lymphovascular invasion } \\
\hline \multicolumn{8}{|c|}{ Perineural invasion } \\
\hline Present & 46 & 51.11 & 24 & 36.34 & 12 & 50 & \multirow[t]{2}{*}{0.088} \\
\hline Absent & 44 & 48.89 & 42 & 63.66 & 12 & 50 & \\
\hline \multicolumn{8}{|c|}{ Carcinoma in situ } \\
\hline Present & 31 & 34.44 & 43 & 65.12 & 16 & 66.67 & \multirow[t]{2}{*}{0.068} \\
\hline Absent & 59 & 65.56 & 23 & 34.88 & 8 & 33.33 & \\
\hline \multicolumn{8}{|c|}{ Coexisting bilharzial infestation } \\
\hline Present & 32 & 35.56 & 22 & 33.33 & 10 & 41.67 & \multirow[t]{2}{*}{0.015} \\
\hline Absent & 58 & 64.44 & 44 & 66.67 & 14 & 58.33 & \\
\hline
\end{tabular}

Table 2: Clinicopathological characteristics of the studied cases of bladder carcinoma and its correlation with CoX-2 expression

\begin{tabular}{|c|c|c|c|c|c|c|c|}
\hline \multirow[t]{2}{*}{ Parameters } & \multicolumn{2}{|l|}{$\mathrm{n}(\%)$} & \multicolumn{2}{|c|}{ Positive COX2 expression } & \multicolumn{2}{|c|}{ Negative COX2 expression } & \multirow[t]{2}{*}{$p$ value } \\
\hline & $(n=90,100 \%)$ & $\%$ & $(n=75,83.3 \%)$ & $\%$ & $(n=15,16.7 \%)$ & $\%$ & \\
\hline \multicolumn{8}{|c|}{ 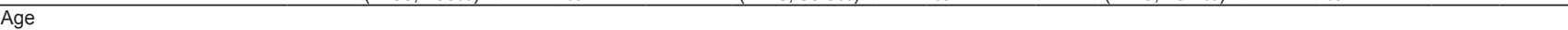 } \\
\hline$\leq 60$ years & 43 & 47.77 & 34 & 45.33 & 9 & 60 & \multirow[t]{2}{*}{0.041} \\
\hline$>60$ years & 47 & 52.22 & 41 & 54.66 & 6 & 40 & \\
\hline \multicolumn{8}{|l|}{ Gender } \\
\hline Male & 73 & 81.11 & 63 & 84 & 10 & 66.67 & \multirow[t]{2}{*}{0.187} \\
\hline Female & 17 & 18.88 & 12 & 16 & 5 & 33.33 & \\
\hline \multicolumn{8}{|l|}{ Tumor size } \\
\hline$<3 \mathrm{~cm}$ & 30 & 33.33 & 26 & 34.67 & 4 & 26.66 & \multirow[t]{3}{*}{0.069} \\
\hline $3-5 \mathrm{~cm}$ & 31 & 34.44 & 24 & 32 & 7 & 46.66 & \\
\hline$>5 \mathrm{~cm}$ & 29 & 32.22 & 25 & 33.33 & 4 & 26.66 & \\
\hline \multicolumn{8}{|l|}{ Grade } \\
\hline Low grade & 36 & 40 & 30 & 40 & 6 & 40 & \multirow[t]{2}{*}{0.020} \\
\hline High grade & 54 & 60 & 45 & 60 & 9 & 60 & \\
\hline \multicolumn{8}{|c|}{ Presence of nodal metastasis } \\
\hline Positive & 25 & 27.78 & 19 & 25.33 & 6 & 40 & \multirow[t]{2}{*}{0.074} \\
\hline Negative & 65 & 72.22 & 52 & 69.33 & 13 & 86.66 & \\
\hline \multicolumn{8}{|c|}{ Muscle invasion } \\
\hline Present & 79 & 87.77 & 55 & 73.33 & 14 & 93.33 & \multirow[t]{2}{*}{0.106} \\
\hline Absent & 11 & 12.22 & 10 & 13.33 & 1 & 6.66 & \\
\hline \multicolumn{8}{|c|}{ Lymphovascular invasion } \\
\hline Present & 36 & 40 & 29 & 38.66 & 7 & 46.66 & \multirow[t]{2}{*}{0.018} \\
\hline Absent & 54 & 60 & 46 & 61.33 & 8 & 53.33 & \\
\hline \multicolumn{8}{|c|}{ Perineural invasion } \\
\hline Present & 44 & 48.88 & 36 & 48 & 8 & 53.33 & \multirow[t]{2}{*}{0.12} \\
\hline Absent & 46 & 51.11 & 39 & 52 & 7 & 46.67 & \\
\hline \multicolumn{8}{|c|}{ Carcinoma in situ } \\
\hline Present & 31 & 34.44 & 25 & 33.33 & 6 & 40 & \multirow[t]{2}{*}{0.034} \\
\hline Absent & 59 & 65.55 & 50 & 66.66 & 9 & 60 & \\
\hline \multicolumn{8}{|c|}{ Coexisting bilharzial infestation } \\
\hline Present & 32 & 35.55 & 28 & 37.33 & 4 & 26.67 & 0.00 \\
\hline Absent & 58 & 64.44 & 47 & 62.66 & 11 & 73.33 & 7 \\
\hline
\end{tabular}


with focal adenoid differentiation (2 cases). There is no significant correlation between expression of FGFR-3 and COX2 in bladder cancer and histological subtypes in this study group as seen in Table 3.

This study also focused on the schistosomal (bilharzial) association in Egyptian patients. One-third of the cases $(35.5 \%)$ showed concomitant affection of this helminth. Table 4 illustrates the further analysis performed on the common significant parameters seen in both FGFR3 and COX2 positive cases associated with schistosomiasis. COX2-associated bilharzial cases demonstrated a positive correlation to CIS $(p=0.009)$. Both FGFR3 and COX2 both showed a positive correlation $(p=0.025)$ and $(p=0.028)$, respectively, in regards to low-grade tumors with bilharzial affection in this study. On the other hand, schistosomal affected cases did not display significant findings in relation to the high-grade tumors that showed FGFR3 and COX2 expression. Likewise, no significant findings were established in regards to size or LVI.

\section{Discussion}

Contrary to the leading etiology of smoking and occupational exposures in Western countries, chronic bladder infection with Schistosoma haematobium has been the most important risk factor for bladder cancer in Egypt [8].
The purpose of this study is to determine any correlation between primary bladder cancers and FGFR-3 and COX-2 protein expression. Furthermore, if there is a possible connection between bilharzialassociation in these tumors and these two markers as the assessment of combined biomarkers instead of a single one will potentially provide a more accurate reflection of the underlying biological complexity of the antitumor immune response. This present study included 90 cases of urothelial bladder carcinomas in Egyptian patients. The ages of the patients ranged from 41 to 79 with a mean age of 64 . These results were close to the results recorded by Arsalan et al. [7] which displayed a mean age of 62.1 years with $89.1 \%$ of the cases diagnosed at more than 40 years of age. Regarding the gender of the cases in this study, the majority were males (81\%), similar to Gust et al. [9], in which $77 \%$ were males.

As for immunostaining for FGFR-3 expression, the current study showed that only 24 cases showed negative staining and the remaining 66 cases $(73.3 \%$ of total cases) showed positive cytoplasmic and/or membranous. Hammam et al. [11] also found that $72 \%$ of malignant cases in their study were also positive for FGFR3 immunostaining, which is compatible with another study [10] that stated that expression of FGFR3 was found in approximately $70 \%$ of both low and high-grade tumors, as well as equally distributed between invasive and non-invasive urothelial carcinoma. Evaluation of the results of immunostaining

Table 3: Histological subtypes and staging of the studied cases and correlation with FGFR3 and COX2 expression

\begin{tabular}{|c|c|c|c|c|c|c|c|c|c|c|c|c|}
\hline \multirow[t]{2}{*}{ Parameters } & \multicolumn{2}{|l|}{$\mathrm{n}(\%)$} & \multicolumn{2}{|l|}{$\begin{array}{l}\text { Positive FGFR3 } \\
\text { expression }\end{array}$} & \multicolumn{2}{|c|}{$\begin{array}{l}\text { Negative FGFR3 } \\
\text { expression }\end{array}$} & \multirow[t]{2}{*}{$p$ value } & \multicolumn{2}{|l|}{$\begin{array}{l}\text { Positive COX2 } \\
\text { expression }\end{array}$} & \multicolumn{2}{|l|}{$\begin{array}{l}\text { Negative COX2 } \\
\text { expression }\end{array}$} & \multirow[t]{2}{*}{$p$ value } \\
\hline & $(n=90,100 \%)$ & $\%$ & $(n=66,73.3 \%)$ & $\%$ & $(n=24,26.7)$ & $\%$ & & $(\mathrm{n}=75,83.3 \%)$ & $\%$ & $(n=15,16.7 \%)$ & $\%$ & \\
\hline \multicolumn{13}{|l|}{ Histological subtype } \\
\hline Urothelial carcinoma & 31 & 34.44 & 22 & 33.33 & 9 & 37.5 & 0.121 & 24 & 32 & 7 & 46.66 & 0.144 \\
\hline Urothelial w/squamous cell differentiation & 12 & 13.33 & 10 & 15.15 & 2 & 8.33 & & 11 & 14.66 & 1 & 6.66 & \\
\hline Squamous cell carcinoma & 23 & 25.55 & 17 & 25.75 & 6 & 25 & & 17 & 22.66 & 6 & 40 & \\
\hline Micropapillary & 4 & 4.444 & 4 & 6.06 & 0 & 0 & & 4 & 5.33 & 0 & 0 & \\
\hline Small cell & 4 & 4.444 & 2 & 3.03 & 2 & 8.33 & & 2 & 2.66 & 2 & 13.33 & \\
\hline Sarcomatoid & 4 & 4.444 & 0 & 0 & 4 & 16.66 & & 0 & 0 & 4 & 26.66 & \\
\hline Non-invasive TCC* & 10 & 11.11 & 10 & 15.15 & 0 & 0 & & 10 & 13.33 & 0 & 0 & \\
\hline TCC $\mathrm{w} /$ focal adenoid differentiation & 2 & 2.22 & 1 & 1.515 & 1 & 4.16 & & 1 & 1.33 & 1 & 6.66 & \\
\hline \multicolumn{13}{|l|}{ Stage } \\
\hline $\mathrm{Ta} / \mathrm{T} 1$ & 19 & 21.11 & 16 & 24.24 & 3 & 12.5 & 0.031 & 17 & 22.66 & 2 & 13.33 & 0.1 \\
\hline T2a & 7 & 7.77 & 6 & 9.09 & 1 & 4.16 & & 4 & 5.33 & 3 & 20 & 09 \\
\hline $\mathrm{T} 2 \mathrm{~b}$ & 7 & 7.77 & 5 & 7.57 & 2 & 8.33 & & 5 & 6.67 & 2 & 13.33 & \\
\hline ТЗа & 14 & 15.55 & 8 & 12.12 & 6 & 25 & & 10 & 1.33 & 4 & 26.67 & \\
\hline T3b & 30 & 33.33 & 21 & 31.81 & 9 & 37.5 & & 20 & 26.67 & 10 & 66.67 & \\
\hline T4a & 12 & 13.33 & 10 & 15.15 & 2 & 8.33 & & 4 & 5.33 & 3 & 20 & \\
\hline $\mathrm{T} 4 \mathrm{~b}$ & 1 & 1.11 & 0 & 0 & 1 & 4.166 & & 1 & 1.33 & 0 & 0 & \\
\hline
\end{tabular}

Table 4: Schistosomal-associated cases with positive FGFR3 and COX2 expression and their correlation to similar tumor parameters

\begin{tabular}{|c|c|c|c|c|c|c|c|c|}
\hline \multirow[t]{2}{*}{ Schistosomal-associated cases } & \multicolumn{2}{|l|}{$\mathrm{n}(\%)$} & \multicolumn{2}{|c|}{ Positive FGR3 expression } & \multirow{2}{*}{$\begin{array}{l}\mathrm{p} \text { value } \\
0.015 \\
\end{array}$} & \multicolumn{2}{|c|}{ Positive COX2 expression } & \multirow{2}{*}{$\begin{array}{l}\mathrm{p} \text { value } \\
0.007\end{array}$} \\
\hline & $(n=32,35.5 \%)$ & $\%$ & $(n=22,33.3 \%)$ & $\%$ & & $(n=28,37.3 \%)$ & $\%$ & \\
\hline \multicolumn{9}{|l|}{ Tumor size } \\
\hline$<3 \mathrm{~cm}$ & 10 & 31.25 & 8 & 36.3 & \multirow{3}{*}{0.075} & 10 & 35.7 & \multirow[t]{3}{*}{0.154} \\
\hline $3-5 \mathrm{~cm}$ & 14 & 43.75 & 7 & 31.8 & & 12 & 42.8 & \\
\hline$>5 \mathrm{~cm}$ & 8 & 25 & 7 & 31.8 & & 6 & 21.4 & \\
\hline \multicolumn{9}{|l|}{ Grade } \\
\hline Low grade & 19 & 59.3 & 14 & 63.3 & 0.025 & 17 & 60.7 & 0.028 \\
\hline High grade & 13 & 40.6 & 8 & 36.3 & 0.109 & 11 & 39.3 & 0.097 \\
\hline \multicolumn{9}{|l|}{ Lymphovascular invasion } \\
\hline Present & 17 & 53.1 & 10 & 45.4 & \multirow[t]{2}{*}{0.173} & 15 & 53.5 & \multirow[t]{2}{*}{0.088} \\
\hline Absent & 15 & 46.8 & 12 & 54.5 & & 13 & 46.4 & \\
\hline \multicolumn{9}{|l|}{ Carcinoma in situ } \\
\hline Present & 14 & 43.7 & 9 & 40.9 & \multirow[t]{2}{*}{0.094} & 13 & 46.4 & \multirow[t]{2}{*}{0.009} \\
\hline Absent & 18 & 56.2 & 13 & 59.1 & & 15 & 53.6 & \\
\hline
\end{tabular}


for COX-2 showed that only 15 cases were negative with the remaining 75 cases $(83.3 \%$ of total cases) showed positive cytoplasmic and/or membranous reactivity. Similar findings were reported in another study, in which $71.6 \%$ of the cases showed COX2 immunoreactivity [30].

When analyzing the tumor grade in this study, close results were similarly reported by Maeng et al. [13], in which the majority $(81.3 \%)$ of the lower-grade tumors (PUNLMP and low-grade UC) demonstrated cytoplasmic positivity for FGFR-3, whereas only $47.8 \%$ of high-grade urothelial carcinomas did $p=0.022$. In a study by Tomlinson et al. [14], FGFR3 was higher in non-invasive ( $p T a)$ compared to invasive ( $p T 2$ ) tumors and was associated with low grade compared with high grade. Both COX-2 and FGFR-3 showed positive correlations to tumor grade ( $p=0.020, p=0.028$ ), respectively. Further, multiple-response analytical statistics were performed, in which low-grade tumors that were positive to COX-2 and FGFR-3 showed a positive correlation ( $p=0.028$ ). This strongly suggests that both COX-2 and FGFR-3 show over-expression more commonly in lower grade urothelial tumors.

The tumor size in this study showed a positive correlation for FGR-3 staining ( $p=0.028$.) This may be attributed to many studies that postulate the link between FGFR-3 expression in lower grade tumors, with a smaller size and lower stage [15]. On the other hand, this study displayed no linear correlation between COX-2 expression and tumor size. Thus, these interesting results similarly supported by Hammam et al. [11], who argued that COX-2 may have more of a tumorigenic role rather than a prognostic impact.

From a histologic standpoint, invasive urothelial carcinoma was the predominant subtype in this study and accounted for $31 \%$ of all cases. There was no significant correlation seen regarding FGFR3 ( $p=0.121)$, similar to Tomlinson et al. [12], who also showed no significant association between FGFR3 mutation status and histologic subtype ( $p=0.106)$. Youssef et al. [18] showed a positive correlation of histologic type and COX-2 ( $p \leq 0.005)$. This discrepancy may be due to a large amount of schistosomal cases ( $n=205)$ in comparison to non-schistosomal cases $(n=110)$ in their study which is associated more commonly with squamous cell histologic variant.

In this study, concomitant in situ changes were evident in only 31 cases (34.3\%). Showing a smaller percentage, Youssef et al. [18] demonstrated that only 29 cases $(9.2 \%)$ showed associated carcinoma in situ. This may be due to a larger percentage of nonpapillary late-stage tumors in their study. Similarly, in our study, an insignificant correlation was seen between FGFR-3 and concomitant in situ changes; however, a positive statistic finding was seen when correlating COX-2 ( $p=0.034)$. Jacobs et al. [20] additionally reported that $93 \%$ of CIS showed COX-2 expression. Moreover, another study [19] reported that $86 \%$ of invasive transitional cell carcinomas, $78 \%$ of non-invasive transitional cell carcinomas, and $75 \%$ of CIS were COX-2 positive. In addition, in $53 \%$ of cases, morphologically normal epithelium adjacent to the cancer lesion was COX-2 positive. They reported that this indicates that morphologically normal epithelial cells may change into tumor cells due to a paracrine effect caused by increased cytokines and/or growth factors [19], [20].

Regarding metastatic tumor deposits to regional lymph nodes, a study performed in Egypt on 315 cases of bladder cancer, showed a positive nodal metastasis of $30 \%$ and positive LVI emboli of $30.5 \%$. However, in our study, a higher percentage $(60 \%)$ of lymphatic invasion was seen [18]. Previous studies have reported that the rate of $\mathrm{LVI}$ ranges from $35 \%$ to $55 \%$ in muscle-invasive bladder carcinoma. Regarding COX-2, no statistical relationship was developed in this study between it and lymph node status nor LVI $(p=0.074$, $p=0.018)$, respectively. On similar terms, a large study performed on 773 bladder cancer patients also showed no statistical relationship to COX-2 regarding lymph node status or invasion $(p=0.296, p=0.869)$, respectively. Yamada et al. [23] observed positive findings between primary COX-2-positive patients and metastatic COX-2-positive patients $(p=0.03)$. This finding is significant since it suggests that metastatic lymph nodes are likely to be COX-2 positive when the primary tumor is COX-2 positive.

A significant correlation was also detected between FGFR3 expression and nodal status, in which FGFR3 expression was seen in $80 \%$ of the cases with positive regional lymph node metastasis ( $p \leq 0.0006$ ). In relation to $\mathrm{LVI}$, another strong correlation was also established in this study $(p=0.0028)$. On the other hand, different findings were found in the study led by Baldia et al. [21], in which no significant finding was seen $(p=0.087)$. This may be due to the fact that the cohort study group was only squamous cell carcinoma patients and did not include other histologic variants.

A positive correlation was analyzed between tumor stage and FGFR3 ( $p=0.031)$. Similar to our findings, Poyet et al. [15] showed a significant association between tumor stage and grade and FGFR3 immunoreactivity (both $p<0.001$ ). Prognostic research involving the grade of bladder carcinomas explained that the overall survival was significantly better in patients with low-grade tumors compared to high-grade tumors $(p=0.011)$ and that patients with stage $\mathrm{pTa}$ had a significantly better overall survival than patients with invasive tumors [31].

The diagnosis of schistosomal bladder cancer was determined based on histological proof of bilharziasis (calcified eggs of $\mathrm{S}$. haematobium) in the studied cases. Of the ninety cases, 32 cases $(35.6 \%)$ showed bilharzial ova. Statistical analysis showed a positive correlation for both COX-2 and FGFR-3 $(p=0.007, p=0.015)$, respectively. Another study 
El-Sheikh et al. [26] showed COX-2 overexpression was associated with pathological $\mathrm{T}$ stage $(p=0.01)$, grade $p<0.001)$, LVI $(p=0.041)$, and bilharziasis $p=0.045)$. Similar results supported that COX-2 expression was significantly higher in schistosomalassociated TCC than in non-schistosomal-associated TCC $(p<0.01)$.

In relation to FGFR3, Hammam et al. [11] showed that $54.5 \%$ of their study cases showed FGFR3 immunostaining and demonstrated a positive correlation of bilharzial bladder cancers and FGFR-3 $(p \leq 0.001)$. Further Chi-square analytical studies were performed to show if a relation between COX2 and FGFR3 exists between the schistosomal-associated cases, in which positive correlation was established between the bilharzial-associated low-grade COX2 and FGFR3 cases ( $p=0.025, p=0.028)$, respectively.

Our second interpretation of the results goes in hand in hand with the fact that normal urothelial cells predominantly express high levels of cyclooxygenase (COX)-1, while bladder cancer cells show COX-2 overexpression [26]. COX2 expression, according to these results, is higher, especially when associated with inflammatory conditions such as schistosomiasis which is predominant in Egypt. According to Kluth et al. [25], combining celecoxib with BCG for schistosomalassociated cases was found to increase tumor infiltration of CD4+ T cells with a significant reduction of tumor burden. Thus, similar to the results of Yamada et al. [23], patients may benefit from treatment with selective COX-2 inhibitors in addition to the usual BCG treatment administered to the schistosomal cases in Egypt to limit progression of the tumor.

\section{Conclusion}

FGFR3 has been revealed to possess an oncogenic role in bladder cancer and mutations are found in up to $80 \%$ of primary low-grade tumors [24]. Our results have shown that FGFR3 expression is positive with low grade and low stage tumors and is statistically supported. Detection of FGFR3 mutations in urine should be employed for general population screening aimed at the early detection of primary tumors [22].

The results of this study established a positive correlation of FGFR3 in relation to tumor size, stage, grade, nodal status, and LVI. As for COX2, we have proven the significant findings in relation to grade, LVI and CIS. Schistosomiasis showed a clear cut correlation to both FGFR3 and COX2 in this study with a strong association to low-grade tumors and CIS areas.

Our recommendation is the consideration of FGFR-3 and selective COX-2 inhibitors for their use alone or in combination with conventional treatment such as intravesical BCG in cases associated with schistosomal infection.

\section{References}

1. Batista $R$, Vinagre $N$, Meireles $S$, Vinagre J, Prazeres $H$, Leão $\mathrm{R}$, et al. Biomarkers for bladder cancer diagnosis and surveillance: A comprehensive review. Diagnostics (Basel). 2020;10(1):E39. https://doi.org/10.3390/diagnostics10010039 PMid:31941070

2. Martino ED, Tomlinson DC, Knowles MA. A decade of FGF receptor research in bladder cancer: Past, present, and future challenges. Adv Urol. 2012;2012:429213. https://doi. org/10.1155/2012/429213

PMid:22899908

3. Pandith AA, Shah ZA, Siddiqi MA. Oncogenic role of fibroblast growth factor receptor 3 in tumorigenesis of urinary bladder cancer. Urol Oncol. 2013;31(4):398-406. https://doi. org/10.1016/j.urolonc.2010.07.014

PMid:20822928

4. Goodison S, Rosser CJ, Urquidi V. Bladder cancer detection and monitoring: Assessment of urine-and blood-based marker tests. Mol Diagn Ther. 2013;17(2):71-84. https://doi.org/10.1007/ s40291-013-0023-x

PMid:23479428

5. Moussa M, Omran Z, Nosseir M, Lotfy A, Swellam T. Cyclooxygenase-2 expression on urothelial and inflammatory cells of cystoscopic biopsies and urine cytology as a possible predictive marker for bladder carcinoma. APMIS. 2009;117(1):4552. https://doi.org/10.1111/j.1600-0463.2008.00014.x PMid:19161536

6. Guancial EA, Werner L, Bellmunt J, Bamias A, Choueiri TK, Ross R, et al. FGFR3 expression in primary and metastatic urothelial carcinoma of the bladder. Cancer Med. 2014;3(4):835-44. https://doi.org/10.1002/cam4.262 PMid:24846059

7. Aliramaji A, Kaseean A, Pasha YR, Shafi H, Kamali S, Safari M, et al. Age distribution types of bladder cancers and their relationship with opium consumption and smoking. Caspian $\mathrm{J}$ Intern Med. 2015;6(2):82-6.

PMid:26221505

8. Felix AS, Soliman AS, Khaled H, Zaghloul MS, Banerjee M, El-Baradie $\mathrm{M}$, et al. The changing patterns of bladder cancer in Egypt over the past 26 years. Cancer Causes Control. 2008;19(4):421-9. https://doi.org/10.1007/s10552-007-9104-7 PMid:18188671

9. Gust KM, Mcconkey DJ, Awrey S, Hegarty PK, Qing J, Bondaruk J, et al. Fibroblast growth factor receptor 3 is a rational therapeutic target in bladder cancer. Mol Cancer Ther. 2013;12(7):1245-54. https://doi.org/10.1158/1535-7163. mct-12-1150 PMid:23657946

10. Kyritsi F, Loffredo CA, Zheng YL, Philips G, Amr S. Urinary bladder cancer in Egypt: Are there gender differences in its histopathological presentation? Adv Urol. 2018;2018:1-7. https://doi.org/10.1155/2018/3453808

11. Hammam $\mathrm{O}$, Aboushousha $\mathrm{T}$, El-Hindawi $\mathrm{A}$, Khairy $\mathrm{H}$ Khalil $\mathrm{H}$, Kamel A, et al. Expression of FGFR3 protein and gene amplification in urinary bladder lesions in relation to schistosomiasis. Open Access Maced J Med Sci. 2017;(2):160-6. 
https://doi.org/10.3889/oamjms.2017.048 PMid:28507621

12. Junker K, Oers JM, Zwarthoff EC, Kania I, Schubert J, Hartmann A. Fibroblast growth factor receptor 3 mutations in bladder tumors correlate with low frequency of chromosome alterations. Neoplasia. 2008;10(1):1-7. https://doi.org/10.1593/ neo.07178

PMid:18231634

13. Maeng YH, Eun SY, Huh JS. Expression of fibroblast growth factor receptor 3 in the recurrence of non-muscleinvasive urothelial carcinoma of the bladder. Korean $\mathrm{J}$ Urol. 2010;51(2):94-100. https://doi.org/10.4111/kju.2010.51.2.94 PMid:20414420

14. Tomlinson D, Baldo O, Harnden P, Knowles M. FGFR3 protein expression and its relationship to mutation status and prognostic variables in bladder cancer. J Pathol. 2007;213(1):91-8. https:// doi.org/10.1002/path.2207

\section{PMid: 17668422}

15. Poyet C, Hermanns T, Zhong Q, Drescher E, Eberli D, Burger M, et al. Positive fibroblast growth factor receptor 3 immunoreactivity is associated with low-grade non-invasive urothelial bladder cancer. Oncol Lett. 2015;10(5):2753-60. https://doi.org/10.3892/ ol.2015.3691

PMid:26722237

16. Wakai $\mathrm{K}$, Utsumi $\mathrm{T}$, Yoneda $\mathrm{K}$, Oka R, Endo T, Yano M, et al. Development and external validation of a nomogram to predict high-grade papillary bladder cancer before first-time transurethral resection of the bladder tumor. Int $\mathrm{J}$ Clin Oncol. 2018;23(5):957-64. https://doi.org/10.1007/s10147-018-1299-y PMid:29804156

17. Shapur N, Pode D, Katz R, Shapiro A, Yutkin V, Pizov G, al. Predicting the risk of high-grade bladder cancer using noninvasive data. Urol Int. 2011;87(3):319-24. https://doi. org/10.1159/000328635

PMid:21849760

18. Youssef RF, Lotan Y. Predictors of outcome of nonmuscle-invasive and muscle-invasive bladder cancer. ScientificWorldJournal. 2010;11:369-81. https://doi.org/10.1100/ tsw.2011.28

PMid:21336453

19. Thanan R, Murata M, Ma N, Hammam O, Wishahi M, El Leithy T, et al. Nuclear localization of COX-2 in relation to the expression of stemness markers in urinary bladder cancer. Mediators inflamm. 2012;2012:165879. https://doi.org/10.1155/2012/165879

PMid:22577245

20. Jacobs BL, Lee CT, Montie JE. Bladder cancer in 2010: How far have we come? CA Cancer J Clin. 2010;60(4):244-72.] https:// doi.org/10.3322/caac.20077

PMid:20566675

21. Baldia PH, Maurer A, Heide T, Rose M, Stoehr R, Hartmann A, et al. Fibroblast growth factor receptor (FGFR) alterations in squamous differentiated bladder cancer: A putative therapeutic target for a small subgroup. Oncotarget. 2016;7(44):71429-39. https://doi.org/10.18632/oncotarget.12198

PMid:27669755

\section{Author Queries???}

AQ6:Kindly cite figures $1-8$ in the text part

AQ7: Kindly cite reference 6 in text part and Duplicate reference $(2,22)$ are found (highlighted). Please check and cite all references in chronological order
22. Martino ED, Tomlinson DC, Knowles MA. A decade of FGF receptor research in bladder cancer: Past, present, and future challenges. Adv Urol. 2012;2012:429213. https://doi. org/10.1155/2012/429213

PMid:22899908

23. Yamada $\mathrm{Y}$, Nakamura K, Inoue $\mathrm{Y}$, Naruse K, Aoki S, Taki T, et al. Cyclooxygenase-2 expression in invasive transitional cell carcinoma of the urinary bladder. Mol Med Rep. 2008;1(6):791-5. PMid:21479487

24. Ehdaie B, Sylvester R, Herr HW. Maintenance bacillus calmetteguérin treatment of non-muscle-invasive bladder cancer: A critical evaluation of the evidence. Eur Urol. 2013;64(4):57985. https://doi.org/10.1016/j.eururo.2013.05.027 PMid:23711538

25. Kluth LA, Black PC, Bochner BH, Catto J, Lerner SP, Stenzl $A$, et al. Prognostic and prediction tools in bladder cancer: A comprehensive review of the literature. Eur Urol. 2015;68(2):238-53. https://doi.org/10.1016/j.eururo.2015.01.032 PMid:25709027

26. El-Sheikh SS, Madaan S, Alhasso A, Abel P, Stamp G, Lalani EN. Cyclooxygenase-2: A possible target in schistosomaassociated bladder cancer. BJU Int. 2001;88(9):921-7.) https:// doi.org/10.1046/j.1464-4096.2001.01649.x

PMid: 11851614

27. Prima V, Kaliberova LN, Kaliberov S, Curiel DT, Kusmartsev S. COX2/mPGES1/PGE2pathway regulates PD-L1 expression in tumor-associated macrophages and myeloid-derived suppressor cells. Proc Natl Acad Sci. 2017;114(5):1117-22. https://doi.org/10.1073/pnas.1612920114

28. Casadei C, Dizman N, Schepisi G, Cursano MC, Basso U, Santini $\mathrm{D}$, et al. Targeted therapies for advanced bladder cancer: New strategies with FGFR inhibitors. Ther Adv Med Oncol. 2019;11:5-9. https://doi.org/10.1177/1758835919890285 PMid:31803255

29. Ishida $\mathrm{K}$, Hsieh MH. Understanding urogenital schistosomiasisrelated bladder cancer: An update. Front Med. 2018;5:223. https://doi.org/10.3389/fmed.2018.00223 PMid:30159314

30. Hassan HE, Mohamed AA, Bakhiet AO, Ahmed HG Immunohistochemical expression of COX2 and iNOS in bladder cancer and its association with urinary schistosomiasis among Sudanese patients. Infect Agents Cancer. 2013;8(1):9. https:// doi.org/10.1186/1750-9378-8-9

PMid:23414519

31. Mhawech-Fauceglia $P$, Cheney $R$, Fischer G, Beck $A$, Herrmann F. FGFR3 and p53 protein expressions in patients with pTa and pT1 urothelial bladder cancer. Eur J Surg Oncol. 2006;32(2):231-7. https://doi.org/10.1016/j.ejso.2005.11.018 PMid: 16412606

32. Ibrahim AS, Khaled HM, Mikhail NN, Baraka H, Kamel H. Cancer incidence in Egypt: Results of the national populationbased cancer registry program. J Cancer Epidemiol. 2014;2014:437971. https://doi.org/10.1155/2014/437971 PMid:25328522 